\title{
Berhagai Teknik Pemeriksaan untuk Menegakkan Diagnosis Penyakit Alergi
}

\author{
Ni Putu Sudewi, Nia Kurniati, EM Dadi Suyoko, Zakiudin Munasir, Arwin AP Akib \\ Departemen Ilmu Kesehatan Anak, Fakultas Kedokteran Universitas Indonesia, RS Dr. Cipto Mangunkusumo \\ Jakarta
}

\begin{abstract}
Angka kejadian penyakit alergi makin meningkat selama tigapuluh tahun terakhir dan tidak jarang mengganggu aktivitas sehari-hari bahkan mengganggu tumbuh kembang anak. Faktor herediter merupakan penyebab terpenting terjadinya penyakit alergi namun paparan lingkungan, infeksi, dan kondisi psikis juga sering kali menjadi faktor pencetus. Tata laksana utama penyakit alergi adalah tindakan pencegahan terhadap alergen penyebab namun tidak jarang alergen penyebab sulit diidentifikasi hanya berdasarkan pada anamnesis. Disamping itu banyak pula kasus alergi dengan gejala menyerupai penyakit lain, maka diperlukan pemeriksaan penunjang untuk membantu menegakkan diagnosis dan menentukan alergen penyebab. (Sari Pediatri 2009;11(3):174-8).
\end{abstract}

Kata kunci: alergi, diagnosis

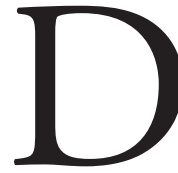
iagnosis alergi ditegakkan berdasarkan anamnesis gejala yang dialami dan kemungkinan alergen penyebab, pemeriksaan fisik untuk melihat gejala alergi yang tampak, dan apabila masih terdapat keraguan harus dilakukan pemeriksaan penunjang. Pemeriksaan penunjang tersebut dapat dilakukan secara in vivo ataupun in vitro.

\footnotetext{
Alamat korespondensi

Dr. Zakiudin Munasir, SpA(K), Divisi Alergi Imunologi Departemen Ilmu Kesehatan Anak FKUI-RSCM, Jl. Salemba 6, Jakarta 10430. Telpon 021-3161144, Fax. 021-3913982.
}

\section{Pemeriksaan in vitro}

\section{Hitung eosinofil total}

Pemeriksaan hitung eosinofil total perlu dilakukan untuk menunjang diagnosis dan mengevaluasi pengobatan penyakit alergi. ${ }^{2}$ Eosinofilia apabila dijumpai jumlah eosinofil darah lebih dari 450 eosinofil $/ \mu \mathrm{L} .{ }^{1}$ Hitung eosinofil total dengan kamar hitung lebih akurat dibandingkan persentase hitung jenis eosinofil sediaan apus darah tepi dikalikan hitung leukosit total. ${ }^{2}$

Eosinofilia sedang (15\%-40\%) didapatkan pada penyakit alergi, infeksi parasit, pajanan obat, keganasan, dan defisiensi imun, sedangkan eosinofilia yang berlebihan (50\%-90\%) ditemukan pada migrasi larva. ${ }^{2}$ 
Dibandingkan IgE, eosinofilia menunjukkan korelasi yang lebih kuat dengan sinusitis berat maupun sinusitis kronis. ${ }^{3,4}$ Jumlah eosinofil darah dapat berkurang akibat infeksi dan pemberian kortikosteroid secara sistemik. ${ }^{1}$

\section{Hitung eosinofil dalam sekret}

Peningkatan jumlah eosinofil dalam apusan sekret hidung merupakan indikator yang lebih sensitif dibandingkan eosinofilia darah tepi, dan dapat membedakan rinitis alergi dari rinitis akibat penyebab lain. Meskipun demikian tidak dapat menentukan alergen penyebab yang spesifik. ${ }^{1,5}$ Esinofilia nasal pada anak apabila ditemukan eosinofil lebih dari $4 \%$ dalam apusan sekret hidung, sedangkan pada remaja dan dewasa bila lebih dari $10 \%$. Eosinofilia sekret hidung juga dapat memperkirakan respons terapi dengan kortikosteroid hidung topikal. ${ }^{1}$ Hitung eosinofil juga dapat dilakukan pada sekret bronkus dan konjungtiva. ${ }^{1,2}$

\section{Kadar serum IgE total}

Peningkatan kadar IgE serum sering didapatkan pada penyakit alergi sehingga seringkali dilakukan untuk menunjang diagnosis penyakit alergi. ${ }^{1,2}$ Pasien dengan dermatitis atopi memiliki kadar $\operatorname{IgE}$ tertinggi dan pasien asma memiliki kadar IgE yang lebih tinggi dibandingkan rinitis alergi. ${ }^{1}$ Meskipun rerata kadar IgE total pasien alergi di populasi lebih tinggi dibandingkan pasien non-alergi, namun adanya tumpang tindih kadar $\operatorname{IgE}$ pada populasi alergi dan non-alergi menyebabkan nilai diagnostik IgE total rendah. ${ }^{1,5}$ Kadar IgE total didapatkan normal pada 50\% pasien alergi, dan sebaliknya meningkat pada penyakit non-alergi (infeksi virus/jamur, imunodefisiensi, keganasan). ${ }^{1,2}$

\section{Kadar IgE spesifik}

Pemeriksaan kadar IgE spesifik untuk suatu alergen tertentu dapat dilakukan secara in vivo dengan uji kulit atau secara in vitro dengan metode RAST (Radio Allergosorbent Test), ELISA (Enzyme-linked Immunosorbent Assay), atau RAST enzim. ${ }^{2,5}$ Kelebihan metode RAST dibanding uji kulit adalah keamanan dan hasilnya tidak dipengaruhi oleh obat maupun kelainan kulit. Hasil RAST berkorelasi cukup baik dengan uji kulit dan uji provokasi, namun sensitivitas RAST lebih rendah. ${ }^{1}$

\section{Pemeriksaan in vivo}

\section{Uji kulit}

Sel mast dengan IgE spesifik untuk alergen tertentu berlekatan dengan reseptor yang berafinitas tinggi pada kulit pasien dengan alergi. Kontak sejumlah kecil alergen pada kulit pasien yang alergi dengan alergen akan menimbulkan hubungan silang antara alergen dengan sel mast permukaan kulit, yang akhirnya mencetuskan aktivasi sel mast dan melepaskan berbagai preformed dan newly generated mediator. Histamin merupakan mediator utama dalam timbulnya reaksi wheal, gatal, dan kemerahan pada kulit (hasil uji kulit positif). Reaksi kemerahan kulit ini terjadi segera, mencapai puncak dalam waktu 20 menit dan mereda setelah 20-30 menit. Beberapa pasien menunjukkan edema yang lebih lugas dengan batas yang tidak terlalu jelas dan dasar kemerahan selama 6-12 jam dan berakhir setelah 24 jam (fase lambat). ${ }^{1}$

Terdapat 3 cara untuk melakukan uji kulit, yaitu cara intradermal, uji tusuk (skin prick test/SPT), dan uji gores (scratch test). ${ }^{6}$

Uji kulit intradermal: 0,01-0,02 ml ekstrak alergen disuntikkan ke dalam lapisan dermis sehingga timbul gelembung berdiameter $3 \mathrm{~mm} .{ }^{1,6}$ Dimulai dengan konsentrasi terendah yang menimbulkan reaksi, lalu ditingkatkan berangsur dengan konsentrasi 10 kali lipat hingga berindurasi $5-15$ mm. ${ }^{6}$ Teknik uji kulit intradermal lebih sensitif dibanding skin prick test (SPT), namun tidak direkomendasikan untuk alergen makanan karena dapat mencetuskan reaksi anafilaksis. ${ }^{1}$

Uji gores (scratch test): sudah banyak ditinggalkan karena kurang akurat. ${ }^{6}$

Uji tusuk (skin prick test/SPT): Uji tusuk dapat dilakukan pada alergen hirup, alergen di tempat kerja, dan alergen makanan. ${ }^{7}$ Lokasi terbaik adalah daerah volar lengan bawah dengan jarak minimal $2 \mathrm{~cm}$ dari lipat siku dan pergelangan tangan. Setetes ekstrak alergen dalam gliserin diletakkan pada permukaan kulit. Lapisan superfisial kulit ditusuk dan dicungkit ke atas dengan jarum khusus untuk uji tusuk. ${ }^{6}$ Hasil positif bila wheal yang terbentuk $>2 \mathrm{~mm}$. Preparat antihistamin, efedrin/epinefrin, kortikosteroid dan $\beta$-agonis dapat mengurangi reaktivitas kulit, sehingga harus dihentikan sebelum uji kulit. Uji kulit paling baik dilakukan setelah pasien berusia tiga tahun. ${ }^{6}$ Sensitivitas SPT terhadap alergen makanan 
lebih rendah dibanding alergen hirup. Dibanding uji intradermal, SPT memiliki sensitivitas yang lebih rendah namun spesifisitasnya lebih tinggi dan memiliki korelasi yang lebih baik dengan gejala yang timbul. ${ }^{7}$

\section{Uji provokasi}

Uji provokasi dilakukan untuk melihat hubungan antara paparan alergen dengan gejala pada berbagai organ (kulit, konjungtiva, saluran cerna, paru), ${ }^{1}$ maka dapat dilakukan uji provokasi.

- Uji provokasi bronkial, ekstrak alergen dengan konsentrasi yang makin tinggi dihirup melalui nebulizer untuk melihat obstruksi jalan napas. Atkins ${ }^{1}$ dalam penelitian menunjukkan bahwa uji provokasi bronkial berkorelasi baik dengan uji kulit maupun uji alergi in vitro.

- Uji provokasi makanan, dilakukan berdasarkan riwayat makanan yang dicurigai serta hasil uji kulit ataupun RAST terhadap makanan tersebut. Pelaksanaannya dapat dilakukan secara terbuka, single-blind, double-blind, atau double-blind placebo-controlled. ${ }^{1}$ Jika uji kulit negatif dan riwayat reaksi terhadap makanan meragukan maka uji provokasi makanan terbuka dapat dilakukan setelah melakukan diet eliminasi selama tiga minggu. Pada uji provokasi susu sapi dilakukan dengan memberikan susu sapi mulai dari 1 tetes $/ 15$ menit hingga $30 \mathrm{ml} / 15$ menit, dan bila telah mencapai $200 \mathrm{ml}$ tidak terjadi reaksi alergi, maka pasien dapat mengkonsumsi susu sapi. ${ }^{8}$

- Uji provokasi sekum (colonoscopic allergen provocationlCOLAP), dilakukan melalui kolonoskopi dengan menyuntikkan ekstrak alergen ke dalam mukosa sekum. Hasil positif berupa pembentukan wheal dan kemerahan pada mukosa. Derajat alergi ditentukan secara semikuantitatif, yaitu $0=$ tidak ada reaksi, $1=$ meragukan, $2=$ reaksi sedang (diameter $<1 \mathrm{~cm}), 3=$ reaksi berat $(1-2$ $\mathrm{cm})$, dan $4=$ reaksi maksimal $(>2 \mathrm{~cm}) .{ }^{10}$ Hasil COLAP sesuai dengan riwayat alergi, namun tidak sesuai dengan hasil SPT dan RAST. Kejadian kemungkinan karena IgE spesifik mukosa usus tidak beredar secara sistemik, atau reaksi hipersensitivitas pada usus bukan (bukan hanya) merupakan mekanisme yang IgE-tergantung.'

- Uji tempel (patch test), pada umumnya digunakan pada kasus dermatitis kontak. Alergen yang dicurigai diletakkan pada kulit dan hasil positif berupa reaksi eksatema dalam 48-72 jam. ${ }^{7}$ Selain pada dermatitis kontak, uji tempel juga dilakukan untuk mendiagnosis alergi makanan pada anak dengan dermatitis atopi dan esofagitis eosinofilik. Dijumpai 67\% anak dengan uji provokasi susu sapi yang positif menunjukkan hasil SPT (reaksi alergi tipe cepat) yang positif, sedangkan uji tempel menunjukkan hasil yang negatif. Sebaliknya, uji tempel positif pada $89 \%$ anak dengan reaksi alergi tipe lambat (25-44 jam). Dikatakan bahwa kombinasi uji tusuk dan uji tempel memiliki nilai prediksi positif tertinggi dan dapat menggantikan uji provokasi makanan. ${ }^{10}$

- Immuno CAP Phadiatop Infant (PI), berguna untuk mendeteksi IgE pada bayi hingga usia 2 tahun. Apabila dibandingkan dengan skin prick test (SPT) dan RAST pada bayi dengan hasil SPT dan RAST seluruhnya positif atau negatif, maka PI memiliki sensitivitas 96\%, spesifisitas 98\%, nilai prediktif positif $89 \%$, dan nilai prediktif negatif 99\% namun pada bayi dengan hasil SPT atau RAST positif, PI menunjukkan sensitivitas $82 \%$, spesifisitas $98 \%$, nilai prediktif positif $94 \%$, dan nilai prediktif negatif $95 \%$. Terdapat korelasi yang bermakna secara statistik antara eksim dan hasil PI yang positif, namun korelasi dengan gejala asma dan rinokonjungtivitis tidak meyakinkan karena di atas usia dua tahun telah terdapat peran infeksi virus. Dengan demikian PI dapat digunakan sebagai pemeriksaan alergi pada bayi karena dapat menggantikan SPT dan tidak memerlukan seleksi antigen spesifik baik pada SPT maupun RAST. ${ }^{11}$

- Microarrayed Allergen Molecules, dapat diketahui molekul alergen penyebab sehingga dapat memberi informasi tentang profit reaktivitas alergi dan dapat mengidentifikasi dengan tepat molekul yang digunakan dalam imunoterapi. ${ }^{12}$ Beberapa dekade yang lampau terdapat berbagai metode pemeriksaan alergi yang saat ini telah ditinggalkan karena tidak sesuai dengan patofisiologi penyakit alergi, antara lain uji alergi sitotoksik (cytotoxic allergy testing), uji provokasi, dan netralisasi (provocative and neutralization testing) secara subkutan ataupun sublingual, imunoterapi dengan titrasi kulit (skin titration method of inzinunotlwrapy), urine autoinjection (autogenous urine immunization), dan pemeriksaan kadar IgG serum terhadap makanan tertentu. ${ }^{13}$ 
Selain berbagai pemeriksaan uji provokasi, akhirakhir ini banyak pula digunakan metode baru yang sebenarnya masih menjadi perdebatan yaitu,

- Uji elektrodermal (electrodermal testing), merupakan salah satu uji alergi yang banyak digunakan dalam complementary and alternative medicine (CAM) sebagai terapi homeopati. Dasar kerja adalah perubahan kecil gelombang listrik pada kulit terjadi pada titik akupunktur sebagai respons terhadap suatu bahan yang diletakkan dalam sirkuit listrik. Dewasa ini penggunaan uji elektrodermal semakin meningkat untuk menentukan status alergi makanan dan alergi hirup, kemungkinan karena faktor keamanannya, tidak invasif, dan sederhana. Namun suatu penelitian buta ganda dengan kontrol dan lebih dari 1500 subjek penelitian menunjukkan bahwa metode uji elektrodermal tidak dapat membedakan antara individu dengan atopi dan non-atopi. ${ }^{14}$

- Terapi Bioresonans (bioresonance therapy), didasarkan pada teori fenomena alergi dapat dijelaskan dengan konsep biofisika. Alergi engram diperlukan untuk proses mekanisme alergi dalam tubuh berlangsung. Alergi engram merupakan cetakan biofisika sebagai dasar predisposisi herediter melalui kontak berulang dengan suatu bahan yang mengiritasi tubuh. Bahan tersebut akan menjadi alergen bagi seorang individu bila telah tercetak sebagai alergi engram dan akan menjadi aktif hanya bila terjadi kontak dengan suatu alergen. ${ }^{15}$

Diagnosis alergi dengan metode biofisika dilakukan dengan meletakkan tuas tensor secara horisontal antara dada pasien dan ekstrak alergen yang akan diperiksa. Bila tensor berayun dengan arah vertikal, (atas-bawah) menandakan pasien alergi terhadap alergen tersebut. Sebelum terapi dimulai, dilakukan proses detoksifikasi dengan cara menggenggam dua logam berbentuk tabung yang dihubungkan dengan kabel ke alat BIOCOM $^{\circledR}$. Proses berlangsung selama 5-10 menit selama 2-3 hari. ${ }^{16}$ Langkah-langkah terapi adalah sebagai berikut, (1) Input cup dihubungkan dengan alat $\mathrm{BIOCOM}^{\circledR}$ melalui dua kabel, (2) Pasien menggenggam dua bola elektroda yang dihubungkan dengan bagian output dari alat, (3) Alat BIOCOM ${ }^{\circledR}$ di-setting dengan frekuensi tertentu sesuai jenis alergen. Terapi untuk satu jenis alergen dilakukan satu kali selama 10 menit namun terapi dapat diulang bila gejala alergi timbul kembali. ${ }^{15}$ Beberapa penelitian dengan menggunakan kontrol menyatakan terapi bioresonans tidak dapat mengenali, mempengaruhi, dan meniadakan alergen. ${ }^{7,16}$ Namun meskipun demikian, hal ini tidak berpengaruh pada popularitas terapi bioresonans yang sangat diminati di Jerman sekitar tahun $1995 .{ }^{16}$

\section{Ringkasan}

Dalam menegakkan diagnosis penyakit alergi dan menentukan alergen penyebabnya tidak jarang diperlukan pemeriksaan penunjang, baik yang dilakukan secara in vivo maupun in vitro. Masing-masing metode memiliki kelebihan dan kekurangan sehingga perlu dikombinasi agar dapat diperoleh diagnosis yang tepat dan tata laksana yang undertreatment maupun overtreatment dapat dihindari.

\section{Daftar Pustaka}

1. Atkins D, Leung DYM. Diagnosis of allergic disease. Dalam: Behrman RE, Kliegman RM, Jenson HB, penyunting. Nelson textbook of pediatrics. Edisi ke-17. Philadelphia: Saunders; 2004.h.747-51.

2. Munasir Z. Pemeriksaan laboratorium. Dalam: Arwin AAP, Munasir Z, Kurniati N, penyunting. Buku ajar alergi - imunologi anak. Edisi ke-2. Jakarta: Ikatan Dokter Anak Indonesia; 2007.h.465-80.

3. Phillips CD, Platts-Mills TAE. Chronic sinusitis : relationship between CT findings and clinical history of asthma, allergy, eosinophillia, and infection. AJR 1995;164:185-7.

4. Paznanovic SA, Kingdom TT. Total IgE levels and peripheral eosinophillia correlation withmucosal disease based on computed tomographic imaging of the paranasal sinus. Arch Otolaryngol Head Neck Surg 2007;133:701-4.

5. Leung DYM. Diagnosis and treatment of allergic disease. Dalam: Leung DYM, Sampson HA, Geha RS, Szefler SJ, penyunting. Pediatric allergy: principles and practice. Edisi ke-1. Missouri; 2003.h.233-51.

6. Munasir Z. Uji kulit terhadap alergen. Dalam: Arwin AAP, Munasir Z, Kurniati N, penyunting. Buku ajar alergi - imunologi anak. Edisi ke-2. Jakarta: Ikatan Dokter Anak Indonesia; 2007.h.445-7.

7. Ruznak C, Davies RJ. ABC of allergies : diagnosing allergy. BMJ 1998; 316:686-9. 
8. Harsono A. Uji provokasi makanan. Dalam: Arwin AAP, Munasir Z, Kurniati N, penyunting. Buku ajar alergi imunologi anak. Edisi ke-2. Jakarta: Ikatan Dokter Anak Indonesia; 2007.h.4556-60.

9. Bischoff SC, Mayer J, Wedemeyer J, Meier PN, ZeckKapp G, Wedi B, Cetin Y, dkk. Colonoscopic allergen provocation (COLAP): a new diagnostic approach for gastrointestinal food allergy. Gut 1997; 40:745-53.

10. Nowak-Wegrzyn A. Future approaches to food allergy. Pediatrics 2003;111:1672-80.

11. Ballardini N, Nilsson C, Nillson M, Lilja G. ImmunoCAP Phadiatop Infant: a new blood test for detecting $\operatorname{IgE}$ sensitisation in children at 2 years of age. Allergy 2006;61:337-43.

12. Hiller R, Laffer S, Harwanegg C, Huber M, Schmidt
WM, Twardosz A, Barletta B, dkk. Microarrayed allergen molecules: diagnostic gatekeepers for allergy treatment. The FASEB Journal express article 10.1096/fj.01-071 fje, 14 Jan 2002.

13. Shapiro GG, Anderson JA. Controversial techniques in allergy. Pediatrics 1988; 82:935-7.

14. Lewith GT, Kenyon JN, Broomfield J, Prescott P, Goddard J, Holgate ST. Is electrodermal testing as effective as skin prick test for diagnosing allergies? A double blind, randomised block design study. BMJ 2001; 322:131-4.

15. Hennecke J, Hennecke SM. Manual of BICOM ${ }^{\circledR}$ bioresonance therapy.

16. Happle R. The essence of alternative medicine. Arch Dermatol 2009; 134:1455-60. 